\title{
POLA KERJASAMA LEMBAGA LITBANG DENGAN PENGGUNA DALAM MANAJEMEN LITBANG (KASUS BALAI PENELITIAN TANAMAN PEMANIS DAN SERAT)
}

\section{PATTERN OF COOPERATION WITH USER RESEARCH INSTITUTE IN MANAGEMENT RESEARCH (CASE STUDY CENTER AND FIBER PLANT SWEETENERS)}

\author{
Iin Surminah \\ Pusat Penelitian Perkembangan Ilmu Pengetahuan dan Teknologi - LIPI \\ Jalan Gatot Soebroto Kavling 10, Jakarta \\ e-mail: iinsurminah77@yahoo.com \\ Dikirim: 13 Maret 2013; direvisi: 5 April 2013; disetujui: 19 Juni 2013
}

\begin{abstract}
Abstrak
Kerjasama merupakan suatu kegiatan bekerja bersama antara satu orang atau lebih secara kooperatif dan menjadi bagian dalam kelompok. Bukan bekerja secara terpisah atau saling berkompetisi.Kerjasama merupakan interaksi dan kompromi dari beberapa elemen yang terkait baik individu, lembaga, dan atau pihak-pihak yang terlibat secara langsung dan tidak langsung yang menerima akibat dan manfaat dari kegiatan kerjasama tersebut. Kompetensi kerjasama menekankan pada peran masing-masing anggota kelompok yang saling bersinergi, dalam menyelesaikan suatu tugas atau proses suatu kegiatan. Tujuan tulisan ini adalah mengkaji pola kerjasama yang dibentuk oleh Ballitas dalam meningkatkan mutu produk yang berdaya saing, faktor-faktor penghambat, dan bagaimana upaya-upaya yang dilakukan ballitas dalam meningkatkan kerjasama. Kajian ini merupakan hasil survei di Balai Penelitian Pemanis dan Serat (Balitas) di Malang, Jawa Timur pada tahun 2012.

Kata kunci: pola kerjasama lembaga litbang dengan pengguna, manajemen litbang, balai penelitian tanaman pemanis dan serat
\end{abstract}

\begin{abstract}
Cooperation is an activity work in conjunction with one or more cooperatively and be part of the group. Instead of working separatedly or mutual compete. Cooperation and compromise is the interaction of some other element that is related to either of an individual, institutions, and or parties involved directly and indirectly who receives due to and benefit from the activities of the cooperation. Competence cooperation of emphasis on the role of each member of a group that is mutually synergize, in completing an errand or process of an activity. The purpose of this paper is to examine the patterns of cooperation in improving the quality of products competitiveness, inhibiting factors, and how the efforts made in enhancing ballitas cooperation. Studies are the result of the survey at balai research sweetening and fibers ( balitas) in Malang, east java in 2012.
\end{abstract}

Keywords: collaboration patternbetween $R \& D$ institution and user, $R \& D$ management, research institute for sweetening and fiber plant

\section{PENDAHULUAN}

Salah satu permasalahan yang dihadapai oleh lembaga litbang dalam mengimplentasikan hasil litbangnya dengan pengguna (industri/UKM/ Masyarakat) adalah kurangnya keterkaitan lembaga litbang itu sendiri sebagai penghasil teknologi dan pengguna (industri/UKM/Masyarakat) sebagai pengguna teknologi. Lembaga litbang kurang memahami kebutuhan dan permasalahaan pengguna dan disisi lain pengguna kurang mengetahui kemampuan yang dimiliki oleh lembaga litbang. Untuk itu masing-masing pihak perlu melakukan peningkatan kemampuannya masing-masing dalam menghasilkan produk yang inovatif dan berdaya saing.
Permasalahan yang dihadapi oleh lembaga litbang dalam membangun kerjasama hasil litbang dengan pihak industri/UKM (stakeholder) meliputi permasalahan kemampuan organisasi, infrastruktur organisasi, kepemimpinan, dan kebijakan, (merupakan permasalahan internal) sedangkan permasalahan keluar lembaga litbang akan menghadapi permasalahan perkembangan iptek, daya saing hasil litbang dari produk impor, pemasaran hasil litbang, belum atau kurang terbentuknya jaringan komunikasi antara lembaga litbang dengan industri, dan belum ada kepercayaan industri terhadap hasil-hasil litbang, serta kurang mampu melakukan inovasi proses dan produk.

Beberapa pendapat mengemukakan bahwa 
sampai saat ini permasalahan yang masih sering terjadi adalah baik lembaga litbang maupun pihak pengguna/stakeholder belum memiliki persepsi yang sama dalam membangun kemampuan daya saing produk industri/UKM untuk meningkatkan daya saing agar dapat bersaing di pasar bebas baik domestik maupun pasar internasional. Sementara pihak pengguna (industri/UKM/masyarakat) tetap memproduksi sesuai kapasitas yang ada tanpa membuat rencana strategis pengembangan produk yang berdaya saing. Dengan demikian hasil produk yang mampu dibuat kurang memenuhi standar mutu yang baik, sehingga kurang mampu bersaing dengan produk yang berasal dari luar.

Sampai saat ini lembaga litbang berperan penting untuk mendukung pengembangan industri berbasis teknologi. Dalam skala makro, dibutuhkan kerjasama antara lembaga litbang dengan pengguna (industri/UKM/Masyarakat) sehingga kegiatan litbang serta kebutuhan pengguna (industri/UKM/ Masyarakat) dapat tersinkronisasi. Untuk mengoptimalkan kerjasama dan lebih mendekatkan pada peran lembaga litbang ditetapkannya UndangUndang (U-U) No18/2002 tentang Sistem Nasional Penelitian, Pengembangan, dan Penerapan Ilmu Pengetahuan dan Teknologi (Sisnasiptek). UndangUndang ini mendorong seluruh organisasi/ institusi/unsur yang terkait dengan iptek untuk bersama-sama menumbuh kembangkan kemampuan dan peran Iptek di Indonesia, sehingga terjadi interaksi yang optimal antar atau diantara lembaga litbang (organisasi/elemen/unsur yang bergerak pada bidang iptek).

Dengan demikian akan membentuk pola kerjasama yang saling memperkuat dan mendorong penguasaan, pemanfaatan, dan pemajuan Iptek. Kemudian operasionalnya tertuang dalam Peraturan Pemerintah (P-P) nomor 20 tahun 2005 tentang alih teknologi, kekayaan intelektual, serta hasil penelitian dan pengembangan oleh Lembaga Litbang dan Perguruan Tinggi, antara lain berhak menggunakan pendapatan yang diperolehnya dari hasil alih teknologi dan/atau pelayanaan jasa iptek untuk mengembangkan diri. Hal ini diperlukan apabila alih teknologi sebagai salah satu strategi kerjasama dapat menghasilkan pendapatan yang kemudian dipergunakan untuk investasi memperkuat infrastruktur lembaga litbang yang pada gilirannya dapat mendorong terjadinya pengembangan iptek.

Lembaga litbang dalam menghasilkan produk hasil litbang merupakan proses yang memerlukan waktu panjang, karena hasil litbang mengalami proses penyempurnaan sampai dianggap selesai dan dapat dipakai oleh pengguna (industri/UKM/ masyarakat). Proses kegiatan litbang ini adalah dimulai dari pengenalan ide, koordinasi, seterusnya sampai proses scale-up yang kemudian tahapan skala pilot (percobaan), apabila berhasil akan dilengkapi dengan studi kelayakan dengan analisis ekonomi, dan dari hasil tersebut siap untuk dikerjasamakan.

Dari perspektif komersial produk litbang, strategi kerjasama sangat dipengaruhi beberapa faktor, seperti: (i) tingkat teknologi yang dihasilkan lembaga litbang yang mampu mampu menunjukkan keunggulannya dibandingkan teknologi yang telah ada dan diterapkan dalam industri/UKM; (ii) nilai ekonomi dari teknologi yang ditawarkan; (iii) apresiasi industri tehadap teknologi dalam negeri; (iv) kemampuan meyakinkan industri/UKM.

Dari uraian tersebut tujuan tulisan ini adalah mengkaji pola kerjasama yang dibentuk oleh Ballitas dengan pengguna (industri/UKM/masyarakat) untuk meningkatkan mutu produk sehingga dapat bersaing dengan produk-produk yang sejenis dari luar. Di samping itu mengkaji pula permasalahan yang dihadapi Ballitas dalam melakukan kerjasama dengan pihak pengguna dan bagaimana alternatif pola kerjasama ke depan yang dilakukan Ballitas.

\section{METODE PENELITIAN}

Jenis penelitian yang digunakan adalah gabungan penelitian eksploratif dan deskriptif. Penelitian eksploratif dilakukan untuk memperoleh informasi yang mendalam yang berkaitan dengan faktor-faktor yang mempengaruhi kerjasma hasil litbang melalui kajian teoritis dan kajian terhadap penelitian terdahulu. Sementara itu, penelitian deskriptif dilakukan karena dalam penelitian ini dibuat deskripsi mengenai fakta-fakta yang berkaitan dengan pola kerjasama antara lembaga litbang dengan pengguna/industri. Subyek penelitian dalam kajian ini adalah kasus yang terjadi di Balai Penelitian Tanaman Pemanis dan Serat (Balittas), Badan Litbang Pertanian yang berlokasi di Malang.

Berbagai program penelitian, pengembangan, dan perakitan teknologi pertanian tepat guna berorientasi pada program pemberdayaan masyarakat bidang pertanian, menciptakan/perakitan ke arah pengembangan dan penerapan teknologi untuk inovasi pertanian dan meningkatkan varitas untuk tananman pemanis dan saerat sehingga mampu meningkatkan kapasitas produksi, produktivitas, diversifikasi, pengembangan varitas dan nilai tambah produk secara berkelanjutan. Kajian ini menggunakan data-data penelitian pada saat peneliti melakukan survei di Balitas, Malang, Jawa Timur pada tahun 2012 .

Jenis data yang dikumpulkan meliputi data primer dan data sekunder. Data primer diperoleh dari hasil wawancara langsung dengan Kepala Balitas dan beberapa peneliti senior untuk menggali pola kerjasama Ballitas dengan pengguna (industri/UKM/petani/Pemerintah Daerah, dll). Data sekunder diperoleh melalui penelusuran bahanbahan, dokumen-dokumen dan hasil penelitian lain yang berkaitan dengan pola kerjasama Ballitas. 


\section{Pengertian Kerjasama}

Pada dasarnya manusia tidak dapat hidup tanpa bantuan orang lain. Dalam menjalani kehidupannya manusia akan dihadapkan pada suatu dilema sosial. Oleh karenanya dibutuhkan kerjasama dalam menjalani kehidupannya (Baron \& Byane, 2000). Faktor yang mempengaruhi kerjasama diantaranya yaitu hal timbal balik, orientasi individu, dan komunikasi. Kerjasama selalu dibatasi oleh periode waktu dan dimulai yang sesaat sampai dalam jangka waktu yang lama, meskipun ada kerjasma yang hampir bersifat permanen. Pihak yang bekerjasama memberikan kontribusi kepada pihak yang lain dan demikian juga sebaliknya, lebih bersifat komplementer. Kontribusi ini menjadi suatu syarat agar terjadi sebuah kerjasama, karena terjadi proses pertukaran nilai antara masing-masing pihak.

Kepercayaan dari masing-masing pihak yang melakukan kerjasama merupakan suatu hal yang sangat penting karena akan diketahui sejauh mana masing-masing pihak dapat memberikan nilai yang diharapkan dari hubungan kerjasama tersebut. Untuk membangun kepercayaan, diperlukan komitmen. Komitmen ini merupakan upaya satu pihak denganpihak yang lain untuk memberikan kontribusi yang telah disepakati. Pemberian komitmen, akan muncul kepercayaan yang kuat di antara pihak-pihak yang bekerjasama. Dalam hal kerjasama, teori biaya transaksi memprediksi bahwa sebuah kerjasama hanya akan terjadi apabila manfaat yang didapat oleh yang bersangkutan lebih besar dari biaya yang dikeluarkan dalam proses menjalin kerjasama tersebut.

Kerjasama dimaksudkan sebagai suatu usaha bersama antara orang perorangan atau kelompok manusia untuk mencapai satu atau tujuan bersama (Soekanto, 1990). Kerjasama (cooperation) adalah suatu usaha atau bekerja untuk mencapai suatu hasil (Baron \& Byane, 2000). Kerjasama adalah adanya keterlibatan secara pribadi diantara kedua belah pihak dami tercapainya penyelesaian masalah yang dihadapi secara optimal (Sunarto, 2000) (dari http://zonemakalah.blogspot.com/2012/03/kerjasama .html, diakses 23/05/2013). Berdasarkan uraian diatas dapat ditarik kesimpulan bahwa kerjasama adalah suatu usaha bersama antara orang perorangan atau kelompok diantara kedua belah pihak manusia untuk tujuan bersama dan mendapatkan hasil yang lebih cepat dan lebih baik. Jika tujuan yang ingin di capai berbeda maka kerjasama tidak akan tercapai. Dengan demikian pengertian kerjasama adalah keinginan untuk bekerja sama dengan orang lain secara kooperatif dan menjadi bagian dari kelompok. Bukan bekerja secara terpisah atau saling berkompetisi. Kompetensi kerjasama menekankan peran sebagai anggota kelompok, bukan sebagai pemimpin. Kelompok disini dalam arti yang luas, yaitu sekelompok individu yang menyelesaikan suatu tugas atau proses (dari Pentingnya Kerjasama. bulusarijaya.blogspot.com/.../pentingnya-kerjasamad, diakses 22/05/2013).

Apabila dasar teori tersebut diterapkan dalam kalangan industri maupun kelompok bisnis yang melakukan kegiatan proses produksi, maka kebutuhan akan pemilihan bahan baku yang baik, sumberdaya manusia yang terampil, dan barang modal inilah yang dapat dijadikan dasar yang kuat bagi hubungan kerjasama dengan pihak lain. Iptek dapat memberi nilai tambah kepada tiga hal mendasar yang menjadi kebutuhan industri tersebut. Sehingga akan terlihat bahwa iptek yang dibutuhkan oleh industri bersifat spesifik dimana yang langsung berhubungan dengan kegiatan proses produksi mereka.

Pengertian kerjasama adalah pekerjaan yang biasanya dikerjakan oleh individu tapi dikerjakan secara bersamaan oleh dua orang atau lebih dengan tujuan agar pekerjaan tersebut menjadi lebih ringan (dari Dwi -Jo, blogspot.com. diakses 2012/02). Kebanyakan bentuk kerjasama dilakukan oleh sekelompok orang atau dalam suatu organisasi dengan organisasi lain atau antara suatu Negara dengan Negara lain. Dengan terbentuknya kerjasama diharapkan memperoleh kemudahaan dalam mencapai tujuan bersama.

Kerjasama dimaksudkan sebagai suatu usaha bersama antara orang perorangan atau kelompok manusia untuk mencapai satu atau tujuan bersama (Soekanto, 1990). Kerjasama (cooperation) adalah suatu usaha atau bekerja untuk mencapai suatu hasil (Baron \& Byane, 2000). Kerjasama (Cooperation) adalah adanya keterlibatan secara pribadi diantara kedua belah pihak demi tercapainya penyelesaian masalah yang dihadapi secara optimal (Sunarto, 2000). Berdasarkan uraian diatas dapat ditarik kesimpulan bahwa kerjasama (Cooperation) adalah suatu usaha bersama antara orang perorangan atau kelompok diantara kedua belah pihak manusia untuk tujuan bersama dan mendapatkan hasil yang lebih cepat dan lebih baik.

Menurut Soekanto (2002), interaksi sosial merupakan hubungan-hubungan sosial yang dinamis menyangkut hubungan antara orang-orang perorangan. Antara kelompok-kelompok manusia, maupun antara orang perorangan dengan kelompok manusia. Bentuk-bentuk interaksi sosial dapat berupa kerjasama (cooperation), persaingan (competition), dan bahkan dapat juga berbentuk pertentangan atau pertikaian (conflict). Interaksi sosial terjadi apabila memenuhi dua syarat (Soekanto, 2002), yaitu: a. Adanya kontak sosial (Social contact); dan b. Adanya komunikasi.

Kerjasama pada intinya menunjukkan adanya kesepakatan antara dua orang atau lebih yang saling menguntungkan, sebagaimana dua pengertian kerja sama di bawah ini:

1. Moh. Jafar Hafsah menyebut kerja sama ini dengan istilah "kemitraan", yang artinya adalah "suatu strategi bisnis yang dilakukan oleh dua 
pihak atau lebih dalam jangka waktu tertentu untuk meraih keuntungan bersama dengan prisip saling membutuhkan dan saling membesarkan."

2. H. Kusnadi mengartikan kerja sama sebagai "dua orang atau lebih untuk melakukan aktivitas bersama yang dilakukan secara terpadu yang diarahkan kepada suatu target atau tujuan tertentu." Dari pengertian kerjasama di atas, maka ada beberapa aspek yang terkandung dalam kerja sama, yaitu: Ada orang-orang (dua orang atau sekelompok orang) yang melakukan kesepakatan untuk mencapai tujuan bersama yang saling menguntungkan. Keberhasilan usah dalam melakukan kerjasama sangat ditentukan oleh peran kedua pihak yang melakukan kerjasama tersebut. Kemudian, kerjasama tersebut terjadi karena adanya aktivitas yang dikehendaki bersama, sebagai alat untuk mencapai tujuan dan ini membutuhkan strategi (bisnis/usaha). Di samping itu merumuskan tujuan/target yang merupakan aspek yang menjadi sasaran dari kerjasama usaha tersebut, biasanya adalah keuntungan baik secara financial maupun nonfinansial yang dirasakan atau diterima oleh kedua pihak. Kerjasama juga akan dibatasi oleh waktu, artinya ada kesepakan kedua pihak kapan kerjasama itu berakhir. Dalam hal ini, tentu saja setelah tujuan atau target yang dikehendaki telah tercapai.

Pentingnya kerjasama disebabkan bahwa pada dasarnya manusia adalah makhluk sosial, yang artinya manusia tidak dapat hidup sendiri tanpa bantuan orang lain. Oleh karena itu dibutuhkan kerjasama dalam menjalankan kehidupan. Adapun manfaat kerjasama sangat besar bagi kehidupan makhluk hidup khusunya manusia, yaitu: (1). Kerja sama mendorong persaingan di dalam pencapaian tujuan dan peningkatan produktivitas; (2). Kerja sama mendorong berbagai upaya individu agar dapat bekerja lebih produktif, efektif, dan efisien; (3). Kerja sama mendorong terciptanya sinergi sehingga biaya operasionalisasi akan menjadi semakin rendah yang menyebabkan kemampuan bersaing meningkat; (4). Kerja sama mendorong terciptanya hubungan yang harmonis antarpihak terkait serta meningkatkan rasa kesetiakawanan; (5). Kerja sama menciptakan praktek yang sehat serta meningkatkan semangat kelompok; dan (6). Kerja sama mendorong ikut serta memiliki situasi dan keadaan yang terjadi dilingkungannya, sehingga secara otomatis akan ikut menjaga dan melestarikan situasi dan kondisi yang telah baik.

\section{Pola Kerjasama}

Ada berbagai pola kerjasama yang biasa digunakan dalam hubungan usaha bisnis. Pola kerjasama yang dikategorikan pola kerjasama sederhana yaitu hubungan bisnis biasa ditingkatkan menjadi hubungan bisnis dengan adanya ikatan tanggung jawab masing-masing pihak dalam mewujudkan kerjasama usaha dengan prinsip saling membutuhkan, salingmenguntungkan, dan saling memperkuat. Secara garis besar dalam kerjasama tersebut, perusahaan/pengusaha besar mempunyai tanggung jawab dalam memberikan bantuan atau kemudahan memperoleh permodalan untuk mengembangkan usaha terhadap pengusaha kecil yang menjadi mitanta. Sedangkan pengusaha kecil mempunyai kewajiban untuk memasokkan hasil produksinya kepada pengusaha besar mitranya dengan jumlah dan standar mutu yang sesuai dengan standar yang telah disepakati bersama.

Pada prinsipnya yang membedakan hubungan dagang biasa dengan kerjasama antara pengusaha besar dengan pengusaha kecil adalah adanya bentuk pembinaan dari pengusaha besar terhadap pengusaha kecil/koperasi. Hal tersebut tidak dapat ditemukan pada hubungan dagang biasa. Untuk mendukung berkembangnyakerjasama usaha membutuhkan peran pemerintah dalam menciptakan iklim yang kondusif bagi pengembangan usaha. Wujud dari peran pemerintah tersebut dapat berupa pemberian fasilitas dan kemudahan dalam berinvestasi, penyediaan/ pembangunan sarana prasarana transportasi, telekomunikasi, listrik serta perangkat perundangundangan yang menclukung kemitraan usaha. Pemerintah diharapkan dapat berperan pula dalam pembinaan terhadap pelaksanaan kerjasama tersebut untuk menghindari terjadinya eksploitasi satu pihak terhadap pihak lainnya.

Pola kerjasamatahap madya, merupakan pengembangan pola kerjasamasederhana di mana peran usaha besar terhadap usaha kecil mitranya semakin berkurang. Bantuan pembinaan usaha besar yang masih sangat diperlukan terutama dalam bantuan teknologi yang dibutuhkan peningkatan produksi dan mutu produksi, industri pengolahan (agroindustri) serta jarninan pemasaran. Dalam aspek periyediaan permodalan pada pola ini pihak usaha besar tidak lagi memberikan modal usaha, tetapi permodalan, manajemen usaha dan penyediaan sarana produksi disediakan oleh usaha kecil. Dalam tingkatan madya ini pihak usaha kecil mampu mengembangkan usaha mulai dari merencanakan usaha serta sampai pengadaan sarana produksi dan permodalan dalam upaya menjamin kelangsungan kerjasama yang dijalin dengan usaha besar. Sedangkan peran pemerintah dan lembaga terkait tetap sama sebagaimana peran dalam pola sederhana yalta sebagai fasilitator.

Pola kerjasamatahap utama, merupakan pola kerjasama yang paling ideal untuk dikembangkan, tetapi membutuhkan persyaratan yang cukup berat bagi pihak yang melakukan kerjasama terutama pihak usaha kecil, karena pola ini membutuhkan kemampuan penguasaan manajerial usaha yang memadai serta pengetahuan bisnis yang luas. Dalam 
pola ini pihak pengusaha kecil secara bersama-sama mempunyai patungan atau menanamkan modal usaha pada usaha besar mitranya dalam bentuk saham. Dengan pemilikan saham dan pengusaha kecil ini dimungkinkan adanya rasa memiliki terhadap perkembangan usaha da perusahan besar mitranya. Demikian pula pihak perusahaan besar mempunyai tanggung jawab yang besar untuk turut mengembangkan usaha kecil rnitranya agar usaha besar yang dijalankan dapat berkembang lebih pesat. Di samping itu adanya beban resiko bersama dalam pola ini menjadikan kerjasama dapat terwujud dengan sinergi saling membutuhkan, saling menguntungkan, dan saling memperkuat sebagaimana yang diharapkan. Keterlibatan pengusaha kecil dalam pengembangan usaha pada perusahan besar pada pola ini mulai dari tahap perencanaan pengembangan usaha sampai pengembangan pemasaran hasil. Peran pemerintah sebagai fasilitator dan pembina kerjasama usaha tetap dibutuhkan sebagaimana pada pola-pola kerjasama yang lain agar dapat terwujudnya kerjasama yang diharapkan.

Pola kerjasama yang disesuaikan dengan jenis pengguna lainnya adalah karena adanya kebutuhan akan teknologi dalam suatu industri/usaha bisnis yang berbeda-beda, tergantung pada bentuk industri dan jenis usaha bisnisnya. Bentuk industri/usaha/bisnis dilihat dari tingkat pembelajaran teknologi terbagi dalam 4 (empat) bagian (Arnold dan Bessant, 1993). Kerjasama dapat berhasil jika lembaga litbang memperhatikan ciri-ciri pengguna/industri yang menjadi mitranya. Tipe pengguna/industri akan menggambarkan kebutuhan dan permasalahannya dan sebaliknya kebutuhan dan permasalahannya dapat mengetahui kompetensi lembaga litbang itu sendiri dalam memenuhi kebutuhan pengguna/industri sebagai mitranya. Perlu juga diperhatikan isu yang berkaitan dan jenis dukungan yang dibutuhkan oleh masing-masing pihak yang melakukan kerjasama. Lembaga litbang dan segi aktivitasnya dapat dibagi menjadi lembaga litbang yang melakukan penelitian dasar, terapan, experimental development, desain dan application engineering, technical services, standardisasi dan sertifikasi. Dilihat dari segi pendanaan ada yang independen, ada yang sepenuhnya ditanggung oleh pendanaan pemerintah serta ada yang semi independen di mana pemerintah hanya memberikan biaya rutin sementara sisanya diperoleh dan kontrak kerja dengan pihak lain.

Dan beberapa literatur, salah satu diantaranya adalah pola kerjasama antara lembaga litbang dengan industri yang dikemukakan oleh Konisi (2000), yaitu Pola kerjasama antara Lembaga Litbang Perguruan Tinggi dengan Industri. Pola kerjasama tersebut terbagi dalam 3 kategori, yaitu Bidang Riset, Bidang Pelayanan, dan Pendidikan/Pelatihan. Pertama, Kerjasama di Bidang Penelitian dan Pengembangan adalah berkaitan dengan kegiatan: Pusat unggulan,
Lembaga riset terapan, Laboratorium, Konsorsium kerjasama riset, Proyek penelitian bersama, Program alih teknologi industri kecil, Konsorsium asosiasi industri, dan Research Park. Kedua, Bidang pelayanan dan konsultasi diantaranya adalah: Unit pelayanan industri, Science Parks, Dewan Teknologi, Lembaga koordinasi pemerintah, Pusat pengembangan, Jaringan alih teknologi, Inkubator, dan Pengujian/Kalibrasi/Perbaikan. Ketiga, Bidang Pendidikan /Pelatihan, adalah; Pendidikan lanjutan, Kerjasania pendidikan, Kursus singkat, Pertukaran personil, Pembelajaran jarak jauh, Pusat pelatihan, dan Pelatihan wirausaha. Dengan demikian, Secara umum kerangka Konishi ini dapat dijadikan acuan dalam membentuk pola-pola kemitraan yang dapat dibangun antara lembaga litbang dan dunia industri.

\section{HASIL DAN PEMBAHASAN}

\section{Gambaran Umum Balai Penelitian Tanaman Pemanis dan Serat (Balittas)}

Balai Penelitian Tanaman Pemanis dan Serat (Balittas) merupakan salah satu unit pelaksana teknis (UPT), Badan Penelitian dan Pengembangan Pertanian yang berada di bawah Pusat Penelitian Perkebunan yang ada di Jakarta. Balittas berlokasi di Jl. Karangploso di Malang. Balittas didirikan atas dasar Keputusan Menteri Pertanian No. 63/Permentan/OT.140/10/2011. Balittas ingin memposisikan diri sebagai lembaga penelitian dan pengembangan pertanian berkelas dunia dalam menghasilkan dan mengembangkan inovasi teknologi pertanian berkelanjutan berbasis sumber daya lokal. Salah satu misi Balai Penelitian Tanaman Pemanis dan Serat (Balittas), sebagai penjabaran dari visi pembangunan pertanian tersebut yaitu mengembangkan jejaring kerjasama Pemerintah dan interPemerintah (networking) dalam rangka penguasaan Iptek (scientific recognition) dan peningkatan perannya dalam pembangunan pertanian (impact recognition).

Perwujudan keinginan tersebut perlu didukung oleh peningkatan kemampuan dan kapasitas SDM penelitinya dalam pemanfaatan dan penguasaan ilmu pengetahuan dan teknologi pertanian, sehingga diharapkan dapat mengembangkan potensi sumberdaya lokal secara optimal. Peningkatan kemampuan tersebut, diantaranya dapat dilakukan melalui pengembangan jejaring kerjasama penelitian antara Pemerintah dengan para pemangku kepentingan (stakeholders) baik ditingkat nasional maupun internasional. Sejak tahun 2007 Badan Litbang Pertanian telah menyelenggarakan kegiatan kerjasama penelitian pertanian.

Telah banyak hasil litbang yang berpotensi untuk dikerjasamakan kepada pihak pengguna. Balittas adalah balai yang didirikan untuk mengembangkan hasil pertanian dan perkebunan di Indonesia di bawah koordinasi Pusat Penelitian dan Pengembangan Perkebunan, Badan Penelitian dan 
Pengembangan Pertanian, Kementrian Pertanian. Balai ini memiliki mandat untuk meneliti tanaman tembakau, serat buah, serat batang dan daun, serta tanaman minyak industri.Balai Penelitian Tanaman Tembakau dan Serat mempunyai tugas pokok melaksanakan penelitian tanaman tembakau, serat buah (kapas dan kapuk), serat batang dan daun (kenaf dan sejenisnya, rami, abaka, dan sisal), dan minyak industri (wijen dan jarak pagar).

Pertimbangan penetapan programdan kegiatan litbang yang hasilnya dapat dikomersialisasi didasarkan pada: a). Kompetensi organisasi yang diyakini hasilnya bisa diterima oleh industri/dunia bisnis/masyarakat umum; b). Permintaan dari pihak dunia bisnis/industri/UKM; dan c). Melayani kebutuhan pemerintah (Pusat dan Daerah).Penetapan program dan kegiatan litbang yang ditetapkan saat ini merupakan kelanjutan dari program dan kegiatan yang telah ditetapkan sebelumnya. Program dan kegiatan ada kesinambungan/berlanjut dan saling terkait/sinerji, sehingga untuk mendapatkan suatu teknologi tentunya harus merupakan rangkain riset yang berkelanjutan, karena banyak tahapan-tahapan yang harus dilalui.

Pengelompokan program/kegiatan yang telah dihasilkan menjadi suatu produk yang dapat dikomersialisasikan, dikelompokkan menjadi: a). program dan kegiatan yang diterima dan dimanfaatkan oleh berbagai kelompok pengguna (Industri/UKM/masyarakatdan sebagainya). Program/kegiatan tersebut merupakan teknologi yang dihasilkan seharusnya menjawab persoalanpersoalan di masyarakat, sehingga teknologi tersebut dapat berguna dan sangat bermanfaat bagi masyarakat yang merupakan kebutuhan masyarakat dan kebutuhan industri; dan b). Dapat memperkaya khasanah Iptek, antara lain mendapatkan HAKI. Namun hanya sebagian kecil hasil iptek tersebut yang dapat di terima oleh industri, sebagian besar lainya masih berupa makalah-makalah yang diseminarkan. HAKI sangat perlu diupayakan karena tanpa perlindungan HAKI dunia industri tidak mau melisensi. Walaupun tidak semua hasil iptek dapat langsung di HAKI kan ataupun dikomersialkan.

\section{Peran Kerjasama Dalam Kegiatan Litbang}

Untuk menghasilkan produk yang diminati oleh pasar, kerjasama dalam kegiatan litbang mutlak diperlukan, karena hampir seluruh tahapan kegiatan litbang memerlukan keterampilan dan keahlian lebih dari satu disiplin ilmu. Menurut Couchman, et al. (2009), kerjasama riset memberikan banyak manfaat bagi lembaga litbang dan mitra yang terlibat, seperti adanya sharing cost and risk, mendapatkan akses terhadap sumber daya yang diperlukan, meningkatkan kemampuan atau kompetensi sumber daya peneliti dan lembaga, juga memperluas jejaring kerja.

Kesulitan yang biasanya ditemui dalam kegiatan kerjasama litbang adalah cara mengelola kerjasama itu sendiri karena mitra yang bekerjasama mempunyai perbedaan dalam berbagai hal, mulai dari budaya kerja, pengalaman, komunikasi dan kemampuan atau keterampilan (Riger, 2002).

Dengan demikian secara umum, nilai-nilai yang mendasari tercapainya sebuah kerjasama litbang antara lain: (1) tujuan yang sama; (2) kesamaan persepsi; (3) kemauan untuk berproses atau bekerja bersama dalam memecahkan masalah yang disepakati; (4) saling memberikan manfaat; (5) adanya keterbukaan atau kejujuran. Prinsip-prinsip ini adalah hal yang mendasar dari hubungan antar manusia didalam lingkungannya.

Untuk memastikan bahwa kerjasama dalam kolaborasi litbang sama-sama menguntungkan, disarankan bahwa para pihak yang bekerjasama harus mempertimbangkan hubungan hirarkis yang setara sehingga akan mengarah pada kerjasama litbang yang lebih setara. (Wolff, et al., 2001). Dalam kerjasama litbang penting untuk melakukan pertemuan secara rutin, mingguan atau dua mingguan mulai dari tahap awal, dan kemudian bulanan, dua bulanan, atau kuartalan sepanjang berjalannya proyek kerjasama. Para mitra kerjasama litbang perlu terlibat dalam seluruh tahapan proyek, mulai dari perencanaan desain, pelaksanaan proyek, menafsirkan temuan, dan menyebarkan hasil kerjasama (Beamish \& Bryer, 1999; Sormanti, et al., 2001).

Hasil dari kerjasama hendaknya dinikmati oleh seluruh mitra yang terlibat, termasuk akses terhadap data dan informasi. Disamping itu, penerbitan publikasi ilmiah sebagai hasil dari kegiatan kerjasama merupakan salah satu indikator penting keberhasilan proyek kerjasama penelitian. Apabila dikaitkan dalam strategi bisnis, maka pengertian kerjasama adalah kerjasama yang dilakukan oleh kedua pihak atau lebih dalam jangka waktu tertentu untuk meraih keuntungan bersama dengan prinsip saling membutuhkan. Karena merupakan suatu strategi bisnis maka keberhasilan kerjasama sangat ditentukan oleh adanya kepatuhan di antara yang bekerjasama dalam menjalankan etika bisnis (Hapsah, 2000). Dengan demikian dapat disimpulkan bahwa kerjasama mencakup: (1). Hubungan (kerja sama) antara dua pihak atau lebih; (2). Kesetaraan antara pihak pihak tersebut; (3). Hubungan timbal balik yang saling menguntungkan atau saling memberi manfaat atau tujuan yang sama.

Kerjasama sebaiknya dalam koridor proses yang dimulai dengan perencanaan, kemudian rencana itu diimplementasikan dan selanjutnya akan dimonitor serta dievaluasi secara terus menerus oleh pihak yang melakukan kerjasama. Dengan demikian terjadi alur tahapan pekerjaan yang jelas dan teratur sesuai dengan sasaran yang ingin dicapai. Karena kerjasama merupakan suatu proses maka keberhasilannya secara optimal tentu tidak selalu dapat dicapai dalam waktu yang singkat. Keberhasilannya diukur dengan pencapaian nilai 
tambah yang di dapat oleh pihak yang bekerjasama baik dan segi material maupun non-material. Nilai tambah ini akan berkembang terus sesuai dengan meningkatnya tuntutan untuk mengadaptasi berbagai perubahan yang terjadi. Singkatnya, nilai tambah yang didapat merupakan fungsi dari kebutuhan yang ingin dicapai. Dengan kata lain keberhasilan kerjasama merupakan suatu resultante dari konsistensi dalam penerapan etika bisnis, perencanaan yang tepat dibarengi dengan strategi yang jitu serta proses pelaksanaan yang selalu dimonitor, dievaluasi dalam lingkungan yang kondusif.

\section{Pola Kerjasama yang Dilakukan Ballitas dengan Pengguna}

Model analitik pola kerjasama Ballitas dengan pengguna adalah pola kerjasama yang sudah terbangun, pola kerjasama ini dipengatruhi oleh faktor-faktor pendorong kerjasama, faktor-faktor penghambat terjadinya kerjasama, dan upaya-upaya membangun kerjasama dengan pengguna. Pola kerjasama ditentukan oleh program litbang dan diturunkan menjadi kegiatan litbang kemudian menghasilkan produk-produk hasil litbang. Dalam membangun kerjasama litbang, pola kerjasama yang dilakukan oleh Balittas didasarkan pada pemecahan masalah dan manfaat yang diperlukan oleh pengguna, pemecahan masalah pada pengembangan IPTEK, dan teknologi yang dikerjasamakan terus berkembang dan tidak ketinggalan jaman. Juga mempertimbangkan faktor-faktor yang memberikan warna bagi pola kerjasama tersebut. Faktor yang mempengaruhi baik secara internal maupun eksternal, faktor hambatan serta langkah-langkah yang sudah dilakukan untuk mendorong terjadinya kerjasama. Hal tersebut dapat digambarkan pada diagram di bawah ini: pengguna,baik secara formal maupun non formal seperti melalui seminar dan pameran yang khusus diadakanuntuk mengetahui kebutuhan pasar (permintaan pengguna). Demikian pula untuk teknologi yang diterapkan atau yang dikerjasamakan kepada pengguna juga disesuai dengan kebutuhan pasar. Hal ini dilakukan dengan jalan: (1) Selalu memantau perkembangan dan mengikuti perkembanagn teknologi baik dari dalam dan luar negeri, misalnya melalui searching HAKI (2) Merancang teknologi masa depan yang disesuaikan dengan kondisi lingkungan.Pengetahuan kebutuhan iptek yang dibutuhkan oleh pengguna didasarkan pada pengetahuan melalui hubungan formal maupun informal yang terjadi pada saat ada pertemuanpertemuan dengan pengguna. Di samping itu kegiatan penelitian selama ini didasarkan pada pengalaman peneliti dalam menjaring keinginan pengguna.Namun kegiatan riset pasar itu sendiri secara formal untuk melihat kebutuhan penggunamemang belum pernah dilakukan.Orientasi pemasaran produk langsung ditujukan pada kebutuhan pengguna. Bahkan untuk lebih menjamin pemasaran sedapat mungkin calon pengguna/industri sudah diikutkan dalam perencanaan produk.

Dengan demikian industri sudah mengetahui dan memahami sejauh mana produk hasil litbang bisa diterima oleh konsumen. Selain menjual produkproduk yang dihasilkan, Balitas juga menyediakan jasa konsultasi teknologi dan riset, studi kelayakan usaha perkebunan, serta pengembagan varitas bahan tananaman unggul dan pertumbuhan tanaman belum menghasilkan (TBM). Meskipun riset pasar tidak dilakukan secara reguler, namun dalam kegiatan pelatihan dan pendampingan kepada pengguna, akan diidentifikasi kebutuhan pengguna. Selain itu, dilakukan secara rutin kunjungan kepada pengguna.Oleh karena itu produk yang dihasilkan

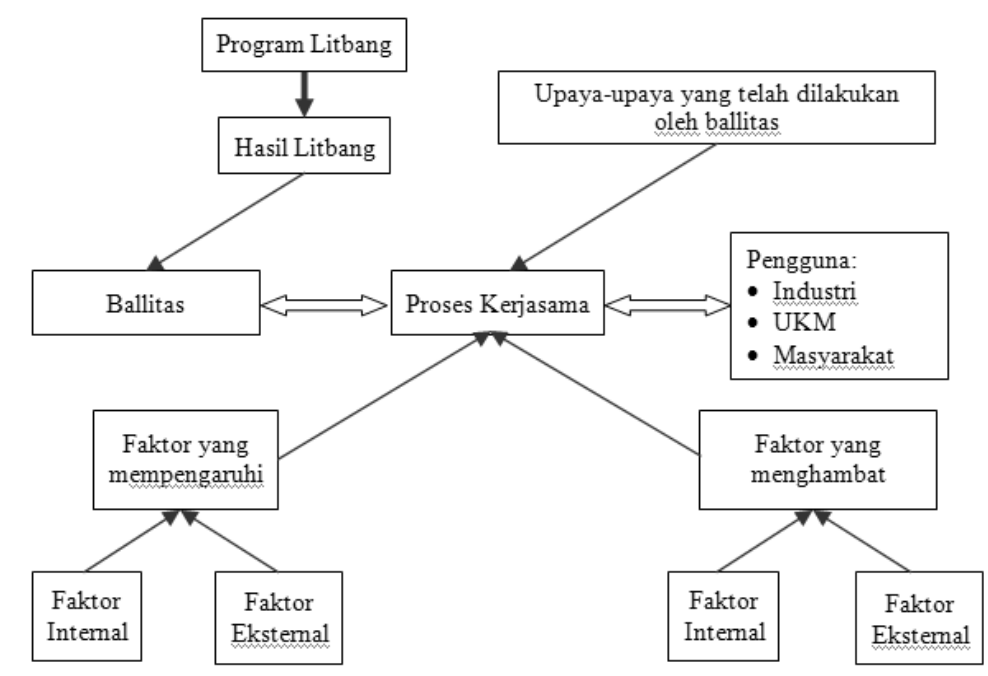

Gambar 1. Pola Kerjasama Yang Telah Dibangun Ballitas.

Untuk mengetahui kebutuhan pengguna dilakukan hubungan baik antara peneliti dengan litbang lebih banyak berdasarkan dari kemampuan peneliti dalam memahami kebutuhan pengguna, 
terutama saat berinteraksi dengan pengguna baik industri, maupun petani. Sumber pendapatan berasal dari hasil inovasi para peneliti, terutama dalam bentuk inovasi paket teknologi dan inovasi benih serta pupuk dan obat hama atau penyakit tanaman, serta jasa konsultasi dan penyuluhan berkaitan bibit, jasa produksi, paket teknologi dan cara penanggulangan hama dan penyakit tanaman.

Pola kerjasama hasil litbang, melalui berbagai proses dan tahapan, dimulai dari pengenalan ide dilanjutkan koordinasi dengan para pengguna yang memiliki posisi pengambil keputusan (Kementrian, Pemda, PT, dan Swasta). Penerapan ide tersebut dikemas dalam bentuk kegiatan litbang namun tetap berdasarkan kompetensi dan infrastruktur penelitiaan yang dimiliki Ballitas. Di samping itu Ballitas tetap konsisten untuk menghasilkan produk yang bermanfaat dan dibutuhkan para pengguna. Pada tahap pelaksanaan maupun setelah selesai dilakukan penelitian selalu diadakan koordinasi dengan berbagai pihak yang baik ditingkat pengambil keputusan dan pengguna akhir. Selalu diadakan rapat koordinasi antara pimpinan dengan para
petani).Dengan cara ini dapat diketahui bentuk kerjasama dapat dilakukan bersama-sama melalui proses yang sifatnya komersial,akan tetapi juga melekat pemberdayaan masyarakat. Bentuk kerjasama yang sifatnya komersial melalui Jasa produksi, jual teknologi, jual varitas unggul, kontrak penelitian, dan konsultasi. Dari bentuk tersebut,pada umumnya memilih jasa produksi. Akan tetapi ada bentuk kerjasama yang diawali permintaan daerah dalam rangka pemberdayaan daerah untuk memecahkan suatu permasalahan tertentu disuatu masyarakat yang menjadi bagian dari proses perubahan dengan melibatkan masyarakat setempat. Bentuk kerjasama ini melibatkan kebijakan pemerintah daerah. Hal ini telah dilakukan oleh Ballitas dengan Pemerintah Daerah di Pulau Jawa dan di luar Pulau Jawa. Kemampuan Ballitas dapat membentuk kerjasama tidak terlepas pula pada kemampuan yang dimiliki oleh pengguna itu sendiri, apakah pengguna memiliki kemampuan yang dapat menyerap teknologi yang dikembangkan oleh Balitas dan didukung oleh potensi sumberdaya alam/daerah. Di lihat dari sisi lembaga litbang, maka Ballitas

Tabel. 1. Pola KerjasamaBallitasDengan Pihak Pengguna/Stakeholder

\begin{tabular}{|c|c|c|}
\hline Konsep Kerjasama terkait dengan & $\begin{array}{c}\text { Mekanisme untuk Memperlancar Pelaksanaan } \\
\text { Kerjasama }\end{array}$ & Stategi Untuk Mencapai Tujuan \\
\hline $\begin{array}{l}\text { - Teknologi tersebut terus berkembang dan } \\
\text { tidak ketinggalan jaman. } \\
\text { - Pemecahan masalah dan manfaat bagi } \\
\text { pengguna (industri/UKM/masyarakat) } \\
\text { - Pemecahan masalah pada } \\
\text { pengembangan IPTEK } \\
\text { - Masukan untuk Kebijakan IPTEK }\end{array}$ & $\begin{array}{l}\text { Mekanisme yang dilakukan: } \\
\text { - Selalu memantau perkembangan dan } \\
\text { mengikuti perkembangan teknologi baik } \\
\text { dari dalam dan luar negeri, misalnya melalui } \\
\text { searching HKI } \\
\text { - Merancang teknologi masa depan yang } \\
\text { disesuaikan dengan kondisi lingkungan } \\
\text { Mengupayakan teknologi tersebut agar } \\
\text { mendapatkan perlindungan HKI } \\
\text { - } \text { Promosi teknologi } \\
\text { - Komersialisasi melalui perjanjian lisensi }\end{array}$ & $\begin{array}{l}\text { - Peningkatan pengetahuan dan } \\
\text { ketrampilan SDM agar teknologi } \\
\text { mendapatkan perlindungan HKI, } \\
\text { cakap dan promosi } \\
\text { Bekerjasama dengan instansi } \\
\text { pemerintah yang lain khususnya } \\
\text { lembaga litbang } \\
\text { Meningkatkan kerjasama dengan } \\
\text { asosiasi UKM, Kadin, lembaga } \\
\text { komersial yang lain }\end{array}$ \\
\hline
\end{tabular}

Sumber: diolah oleh penulis dari hasil wawancara

peneliti senior maupun yunior, dan pejabat administrasi untuk merespon kebutuhan pengguna, kemudian dilanjutkan sampai semua kebutuhan dan permasalahan pengguna dapat dipecahkan. Tahap berikutnya apabila hasil penelitian telah selesai,kemudian diadakan pengujian dan diseminasi melalui pendidikan dan pelatihan kepada para pengguna. Dengan demikian bentuk kerjasama lebih bersifat jasa pelatihan dan pembinaan.

Dalam hal melakukan monitoring dan evaluasi terhadap kerjasama dapat disesuaikan dengan bentuk kerjasamanya. Oleh sebab itu waktu evaluasi pun dapat dilakukan setiap bulan atau tiga bulanan. Untuk membangun kerjasama dengan pengguna dalam menerapkan hasil litbang sangat ditentukan oleh dari kepakaran peneliti yang menyampaikan/mempromosikan hasil litbang tersebut, atau melalui pameran teknologi, bahkan ikut menentukan adalah seminar/workshop, namun dapat pula terjadi kerjasama melalui permintaan langsung pengguna (dunia bisnis/UKM/masyarakat memiliki potensi hasil-hasil litbangnya cukup beragam dan memiliki daya saing, memiliki kemampuan sarana dan infrastruktur yang memadai, namu dari segi dana penelitian relative cukup baik.

Selama ini Ballitas membangun kerjasamadengan bebagai kelompok pengguna. Beberapa kelompok pengguna, diantaranya adalah: (1)Pola kerjasama dengan swasta/industri; (2) Pola kerjasama dengan lembaga litbang lain; (3) Pola kerjasama dengan Litbang Kementrian dan Pemerintah daerah; dan (4). Pola kerjasama dengan masyarakat petani. Ke 4 kelompok pengguna tersebut mempunyai ciri yang berbeda-beda. Namun pada prinsipnya dari seluruh pola kerjasama tersebut harus mengedepankan prinsip saling memberi kontribusi dan masing-masing pihak yang bekerjasama dapat memperoleh manfaat yang saling menguntungkan.

\section{Faktor Penghambat dalam Kerjasama}

Faktor penghambat kerjasama antara Ballitas 
dengan pengguna merupakan permasalahan kerjasama yang harus diatasi, yaitu terbatasnya infrastruktur litbang oleh kondisi sumberdaya litbang (SDM, anggaran/dana, sarana dan prasarana, peralatan teknologi, dsb). Terbatasnya sumber daya litbang adalah: Pertama: masalah SDM, yaitu: (a). pendapat dari sebagian peneliti/perekayasa bahwa teknologi tersebut dapat langsung dipakai masyarakat, sehingga tidak harus/perlu komersial, karena pembiayaan dana penelitian adalah dari uang rakyat, (b). kesadaran yang kurang perlunya perlindungan HKI, (c). penelitian kurang/tidak berorientasi dalam bisnis. Kedua masalah anggara/dana penelitian, yaitu: sering terputus ditengah jalan dan tidak berlanjut, serta tidak memadai untuk menghasilkan suatu teknologi yang komersial, walaupun berlanjut perlu waktu yang cukup lama karena dana terbatas. Ketiga: masalah teknologi, yaitu: pada saat teknologi didapatkan akan tetapi sudah ketinggalan jaman. Keempat: masalah sarana dan prasarana, yaitu: ada keterbatasan mengenai infrastruktur (sarana dan prasarana), apabila sarana dan prasarananya ada namun harganya terlalu mahal. Hal-hal tersebut di atas sebetulnya kita dapat menghasilkan teknologi yang andal apabila mendapat kepercayaan penuh dan dorongan dari pemerintah untuk menghasilkan teknologi tersebut. Misalnya Ballitas sudah bisa menciptakan varietas hibrida unggulan tetapi pemerintah masih saja mengimport varietas sejenis.

Terbatasnya program riset yang didasarkan pada permintaan dan kebutuhan pengguna. Namun sesungguhnya penggunapun perlu hasil riset. Hanya disini memang terlihat kurang keharmonisan antara lembaga riset dengan dunia usaha. Sebetulnya hasil litbang yang dihasilkan oleh lembaga litbang banyak dan kompetitif, namun hasil-hasil tersebut kurang diketahui atau kurang diminati oleh industri. Walaupun ada perbedaan-perbedaan, namun seyogyanya hasil litbang nasional/dalam negeri perlu mendapatkan prioritas untuk dikembangkan dibandingkan hasil litbang yang berasal dari lembaga litbang luar, bila itu hasil litbang untuk produk sejenis. Dengan demikian peneliti kita bisa mendapatkan/menikmati keuntungan finansial dari hasil karyanya.

Iklim/kebijakan merupakan salah satu faktor penghambat komersialisasi litbang, karena kebijakan yang terkait dengan aspek komersialisasi (misalnya PNBP, BLU, dsb). Misalnya yang menyangkut PNBP, dalam penggunaan anggaran untuk penelitian dari PNBP harus sudah direncanakan tahun sebelumnya (sesuai DIPA). Melalui PNBP, dana hasil penelitian tidak dapat dimanfaatkan langsung. Perlu aturan tambahan/juklak khusus agar PNBP tersebut dapat terdistribusi ke Peneliti, UK/UPT, unit pengelola alih teknologi. Perlu maksimum royalti agar PNBP hasil penelitian dapat masuk dan digunakan untuk penggunaan royalti.

\section{Upaya yang Dilakukan Ballitas dalam Meningkatkan Kerjasama}

Ballitas berusaha secara terus-menerus mengoptimalkan penerapan hasil-hasil penelitian kepada pengguna melalui inovasi produk dan proses teknologi untuk mendorong percepatan kemajuan industri dalam upaya memperkuat daya saing industri Indonesia. Seperti kita ketahui bahwa daya saing suatu negara ditentukan oleh banyak faktor, diantaranya adalah kesiapan dalam penyerapan dan penguasaan teknologi dan kemampuan berinovasi. Ada beberapa strategi yang akan dilakukan Ballitas bersama Kementrian Pertanian untuk mempercepat hasil inovasi yang kemudian hasil inovasi yang dilakukan bisa segera dikomersialisasikan. Karena sampai saat ini hasil-hasil penelitian litbang di Indonesia sulit untuk dikomersialisasikan..Oleh sebab itu strategi yang yang perlu dijalankam oleh Ballitas khususnya dan Badan Litbang Pertanian pada umumnya adalah sejak awal penelitiannya, peneliti perlu bekerjasama dengan dunia usaha industri. Gunanya, untuk mencari berbagai permasalahan dan kebutuhan apa yang dihadapai dan dibutuhkan oleh pengguna (industri/UKM/ masyarakat). Sebetulnya Ballitas telah berupaya mengetahui kebutuhan dan permasalahan yang dihadapi pengguna, walaupun memang secara formal tidak dilakukan survey untuk mengetahui kebutuhan dan permasalahan pengguna.

Perlu membangun kemampuan yang lebih profesional lagi baik secara internal maupun ektrenal. Di samping itu perlu dipertegas lagi Visi, Misi, tugas pokok yang sudah ada dengan pembagian tugas yang semakin jelas dan beberapa produk yang telah dihasilkan dan terbangun kerjasama dengan pengguna kedepannya harus semakin profesional dengan jangkauan yang lebih luas lagi. Oleh karena itu tugas pokoknya lebih diarahkan pada pengembangan yang implementasinya menyangkut masyarakat bisnis secara luas dengan perencanaannya pun harus menjangkau hal yang lebih luas dengan senantiasa berorientasi pada pengambil keputusan yang lebih tinggi dari pimpinan Ballitas sampai kepada Kepala Badan Litbang Kementrian Pertanian.

Beberapa strategi untuk meningkatkan kerjasama dalam mengimplentasikan program adalah dilakukan beberapa strategi, yaitu: (1). melakukan pendekatan dan menggali sumber 2 kerjasama baik luar negeri maupun dalam negeri; (2). meyampaikan secara proaktif hasil-hasil penelitian melalui seminar/workshop/roadshow dengan pengguna; (3). menyusun bank proposal komoditas hasil litbabg Ballitas sebagai bahan kerjasama penelitian; (4). Memperkuat dan memperluas jejaring kerja dengan lembaga litbang lain baik pemerintah dan perguruan tinggi untuk mengoptimalkan penggunaan, menghilangkan tumpang tindih penelitian, 
kovergensi program litbang dan meningkatkan kwalitas penelitian; (5). Memperkuat keterkaitan dengan swasta, lembaga penyuluhan, dan pengambil kebijakan dengan melibatkan mereka pada tahap penyusunan program dan perancangan penelitian untuk mengefektifkan desiminasi hasil penelitian; (6). Meningkatkan keterlibatan jejaring kerja internasional, baik bilateral, multilateral, maupun regional; (7). Untuk kerjasama bilateral focus kegiatan tergantung kepada tingkat kemajuan negara2 mitra sumberdaya. Model konseptual yang dikembangkan di negara maju seperti Amerika, telah menumbuhkan kerjasama Universitas dengan Industri. Konseptual Model tersebut menunjukkan bahwa Perguruan Tinggi atau Lembaga litbang harus memiliki Pusat Inovasi, namun untuk Balitbang Pertanian sudah ada yang disebut Balai Pengelolaan Alih Teknologi Pertanian (BPATP) dengan tugas pokok melaksanakan pengelolaan kekayaan intelektual dan alih teknologi hasil kegiatan penelitian dan pengembangan pertanian.Unit kerja ini berada di bawahSekretariat Badan Litbang Pertanian.

Dari kemampuan dan keahlian yang dimiliki Ballitas merupakan modal dasar untuk mengambil peran-peran yang strategis dan dengan demikian dapat pula pengguna (industri/UKM/masyarakat) akan menerima penawaran untuk membangun kerjasama setelah mengetahui dan memahami kemampuan unit litbang. Dimungkinkan selanjutnya pengguna juga akan kondisi kompetensi yang dimiliki. Sehingga Ballitas juga akan memahami kebutuhan dan masalah penggunanya dalam menghadapi persaingan yang semakin berat. Kemudian Ballitas segera merespon dan mengambil langkah-langkah strategis dengan menawarkan suatu kerjasama yang diharapkan oleh kedua belah pihak.

\section{SIMPULAN}

Kerjasama antara Ballitas dengan pengguna merupakan suatu upaya yang sungguh-sungguh untuk melihat sejauhmana hasil pengembangan produk teknologi mampu mendorong perbaikan mutu produk penggunanya (industri/UKM/masyarakat) dalam menghadapi persaingan di era global yang melanda bangsa dan negara Indonesia. Namun hanya sebagian kecil hasil iptek tersebut yang dapat diindustrikan, sebagian besar lainya masih berupa makalah-makalah yang diseminarkan. Memang tidak mudah untuk merancang penelitian yang menghasilkan teknologi yang dapat diterapkan di dunia industri. HAKI sangat perlu diupayakan karena tanpa perlindungan HAKI dunia industri tidak mau melisensi.

Pola kerjasama hasil litbang yang dilakukan oleh Ballitas didasarkan pada dengan Visi, Misi, tugas, dan fungsi sebagai lembaga litbang yang mengembangkan hasil litbang bidang perkebunan khususnya tanaman serat dan termbakau. Pola kerjasama yang telah terbentuk oleh Ballitas secara formal dilihat dari segi penggunanya adalah: kerjasama dengan masyarakat/UKM/koperasi; kerjasama dengan lembaga litbang lainnya dan pengguruan tinggi; kerjasama dengan Pemerintah Daerah; dan kerjasama Industri dan pelaku bisnis lainnya.

Namun dalam mengembangkan kerjasama Ballitas masih menghadapi permasalahan dengan alasan klasik, seperti keterbatasan SDM yang memiliki visi dan misi bisnis ke depan dan keterbatasan anggaran untuk melakukan kerjasama penelitian dan pengembangan. Untuk itu beberapa upaya untuk mendorong kerjasama perlu dukungan pimpinan yang lebih aktif untuk membangun jaringan kerja dengan lembaga litbang lainnya baik di dalam negeri maupun di luar negeri. Perlu adanya studi/kajian lebih lanjut mengenai kebijakan yang berpihak pada pengembangan iptek untuk mendorong kerjasama lembaga litbang dan pengguna dalam rangka pengembangan industri dalam negeri.

\section{DAFTAR PUSTAKA}

Baron, Robert A., Donn Erwin Byrne.2000. Social Psychology. 9th Edition. Pinted In The United State Of America

Benyamin, Setiawan. 2008. Strategi Pengembangan Industri Bioteknologi Indonesia. PT Kalbe Farma. Jakarta.

Berdergue, A. 2005. Pro-Poor Inovation System. International Fund For Agricultural Development (IFAD)-UN

Marsudi Ari. 2002. Hubungan Diklat, Motivasi Kerja dan Budaya Organisasi dengan Produktivitas Peneliti, Tesis. Universitas Indonesia, Jakarta. Tidak Dipublikasikan.

Garfield, E. 1979. Is citation analysis a legitimate evaluation tool?. Scientometrics.

Hafsah, M. J, 2000, Kemitraan Usaha: Konsepsi dan strategi, Pusaka Sinar Harapan, Jakarta.

Harary, F. 1969. Graph Theory. Addison-Wesley, Reading, MA, 1969.

Kotler, Philip. 1995, Manajemen Pemasaran: Analisis, Perencanaan, Implementasi dan Pengendalian, Edisi ke delapan, Edisi Indonesia. Indonesia Empat.

Lembaga Pengembangan Inovasi, 2002, Komersialisasi Produk Litbang: Sebuah Proses Pembelajaran, Jakarta.

Moleong, Lexy J. 1988. Metode Penelitian Kualitatif. PT. Remaja Pusada Karya. Bandung.

Poerwandari, E. Kristi. 2001. Pendekatan kualitatif untuk penelitian perilaku manusia. LPSP 3 : Fakultas Psikologi Universitas Indonesia.

Pettigrew, Andrew and Whipp, Richard. 1996. Unggul bersaing Melalui Inovasi, Bisnis Mutakhir. Abdi Tandur. Jakarta.

Prihanto, I.G. 1996. Kajian Kolaborasi Peneliti Bidang Kedirgantaraan tahun 1975-1994. Tesis. Jakarta: Universitas Indonesia. 
Rufaidah, Vivit Wardah, 2008. Kolaborasi dan Graf Komunikasi Artikel Ilmiah Peneliti Bidang Pertanian;.......". Jurnal Perpustakaan Pertanian Vol.17 Nomor 1 th.2008

Septiyantono, T. 1996. Kolaborasi . Majalah Kedokteran Indonesia. Universitas Indonesia.Jakarta:

Singarimbun, M.Efendi, S, ed. 1989. Metode Penelitian Survei. LP3ES. Jakarta.

Silviera, Mary Pat W, 1985. Research and Development Linkages to Productiuon in Countries", United Nation Science and Technology for Development Series, Westview Press.

Soekanto, S. 2002. Sosiologi suatu pengantar. Edisi 4. Jakarta : PT. Raja Grafindo Persada. Jakarta

Sormin, Remi. 2009. Kajian Korelasi Antara Kolaborasi Peneliti dan Produktivitas Peneliti Lingkup Badan Litbang Penelitian. Jurnal Perpustakaan Pertanian Vol.18 Nomor 1 th.2009

Sulistyo-Basuki. 1990. Kolaborasi. Majalah Ikatan Pustakawan Indonesia . Jakarta.

Sulistyo-Basuki. 1993. Kolaborasi.Jurnal Perpustakaan dan Ilmu Informasi 1(1): 1-15. Jakarta.

Sulistyo-Basuki. 1994. Sebuah kajian teori graf (graph theory) terhadap kolaborasi penulis kedokteran dan pertanian Indonesia 1952-1959. Majalah Universitas Indonesia (4): 34-40.

Subramanyam, K. 1983. Bibliometrics studies of research collaboration: A review. Journal of Information Science 6(1): 34

Soekanto, 1999. Bentuk Kerjasama (Cooperation)Pada Interaksi Sosial Waria, dalam

Bunga Fajar Sari, ..... (http:// eprints.undip.ac.id/24431/1/IMA_OKTORINA.pd f, diakses 7 Januari 2013)

Sumaryanto, Y. 1987. Suatu Kajian Bibliometrika Terhadap Pola Kepengarangan. Artikel yang Dimuat di Majalah Ilmiah Terbitan Indonesia. Skripsi. Universitas Indonesia.Jakarta

Sunarto, 2002. Bentuk Kerjasama (Cooperation)Pada Interaksi Sosial Waria, dalam

Bunga Fajar Sari,

.....(http://eprints.undip.ac.id/24431/1/IMA_OKT ORINA.pdf, diakses 7 Januari 2013)

Surtikanti, R. 2004. Kajian Kolaborasi Interdisipliner Peneliti di Indonesia:Studi kasus pada program riset unggulan terpadu I-VII. Tesis. Universitas Indonesia.Jakarta.

Yin, R. K. 2002. Studi Kasus : Desaian Dan Metode. PT. Raja Grafindo Persada.Jakarta.

--Pentingnya Kerjasama. (http://bulusarijaya. blogspot.com/.../pentingnya). Diakses 22 Juni 2013

--Kerjasama. (http://zonemakalah.blogspot. com/2012/03/kerjasama.html).Diakses 23 Juni 2013. 
